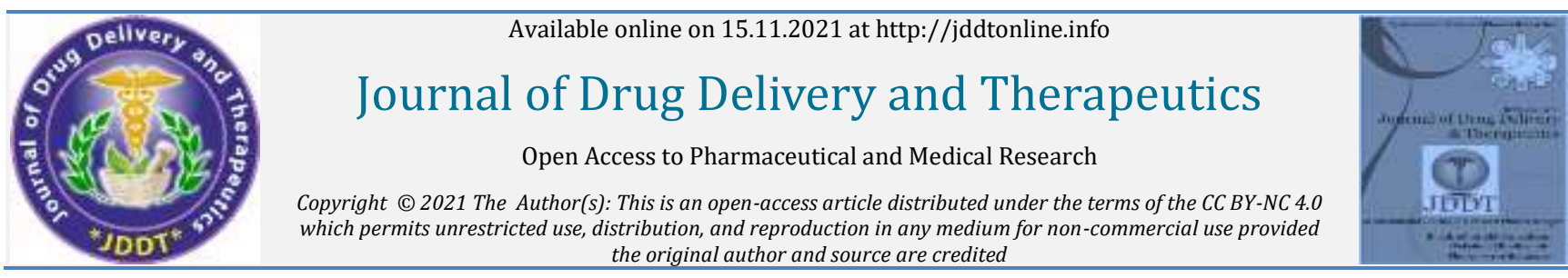

Open Access Full Text Article the original author and source are credited

Review Article

\title{
A Review on medicinal plants in dentistry
}

\author{
Omji Porwal*, Duran Kala \\ Department of Pharmacognosy, Faculty of pharmacy, Tishk International University-Erbil, Kurdistan Region, Iraq
}

Article Info:

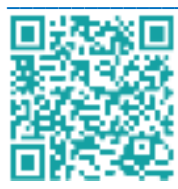

\section{Article History:}

Received 04 October 2021

Reviewed 08 November 2021

Accepted 11 November 2021

Published 15 November 2021

Cite this article as:

Porwal 0, Kala D, A Review on medicinal plants in dentistry, Journal of Drug Delivery and

Therapeutics. 2021; 11(6):332-340

DOI: http://dx.doi.org/10.22270/jddt.v11i6.5128

*Address for Correspondence:

Dr. Omji Porwal, Professor (Full), Faculty of

Pharmacy, Tishk International University, $100 \mathrm{mt}$.

Street, near Filkey Baz (Square), across Qazi

Muhammad, 44001, Erbil, KRG/IRAQ

\section{Abstract}

The dental afflictions are indubitably the most important global infectious diseases affecting both children and adults. The most significant dental illness is dental caries and periodontal pathologies. The major reason of oral health troubles is more inhabitants with pathogenic bacteria and for this reason, conservative treatment can often be in efficient because of bacterial resistance or may have unpleasant side effects.For that reason, studies in the field have focused on finding new therapeutic alternatives. The use of natural medicines for dental care is an ancient cross-cultural practice that persists in the majority of cultures today.Over the past decade, interest in drugs derived from medicinal plants has markedly increased. This study was designed at a literature review focusing on studies investigating herbal drugs and their therapeutic application, mechanism of action, side effects, toxicities and probable drug interactions. A small number of studies were established to hold their rational employ in dentistry. Because there is a rising employ of phytotherapeutic agents in dentistry, additional studies are required to evaluate their safety and efficacy for clinical use.

Keywords: Herbal medicine, Oral health, Dentistry, Caries, Infections

\section{Introduction}

The employ of medicinal plants has a long history in therapeutic and dental practice and they have long been used worldwide ${ }^{1-3}$. Anti-inflammatory, antidiabetic, Anticancer, Huntington's disease, antibacterial, analgesic, sedative agents, endodontic irrigants and antioxidant properties of plants with their biocompatibility explain the people's growing attention in the use of herbal medications ${ }^{4-12}$.With the knowledge of curative properties of the medicinal plants against oral microorganisms and their incorporation in clinical practice we can aim to reduce if not remove this disease entity. Medicinal plants though produce slow recovery but their therapeutic effect is miraculous ${ }^{13}$. Above the earlier period, pharmaceutical companies have been involved in examined plants as basis for new phytotherapeutic agents with established efficiency, quality and safety 14-16. Dental pathology is a worldwide fitness difficulty, disturbing both undersized and rising or urbanized countries. The most widespread oral pathologies are dental caries and periodontal disease and the gravest oral pathologies are oral and pharyngeal cancer and oral tissue lesions are too of important concern ${ }^{17}$. For these causes, the WHO believes that oral health is a right of every people ${ }^{18}$. An additional matter facing oral health is the huge number of children who are pretentious by tooth decay ${ }^{19}$. There are presently various treatments for oral pathologies, but these have disagreeable side consequences, such as altered oral microbiota or systemic gastrointestinal symptoms. Above 750 species of bacteria occupy the oral cavity (50\% of which are yet to be identified) and a figure of these are concerned in oral diseases ${ }^{20}$. Therefore, there is a sensitive require for novel options to conservative treatments, medicinal plants being a region of attention. A significant instance in which plants locate their usefulness is the treatment of bacterial infections at the oral height since most conservative antibiotics are unsuccessful because of bacterial resistance and those that are efficient have disagreeable side consequences ${ }^{21}$. Because of this, natural compounds are a safer substitute to antibiotics in the treatment of oral infections and are too an approach in the deterrence and treatment of additional oral diseases, counting dental caries, but also additional grave diseases such as cancer. Consequently, the reason of this review is to present several new examples of customary medicinal plant extracts or phytochemicals that have been exposed to slow down the enlargement of oral pathogens, decrease the development of dental plaque and decrease the indications of oral illness.

\section{Materials and Methods}

The Medline, Pub Med and Google Scholar databases were electronically investigated for pertinent articles and books available in English using the keywords medicinal plant, herb, phytotherapy, dentistry and pediatric.

\section{Overview of the use of plants in dentistry}

Medicinal plants are a subject of attention for present investigates in the meadow of medicine, being ever more employed for the treatment of a great number of pathologies. Furthermore, numerous drugs presently employed in allopathic medicine have their source in medicinal plants. So, plants are together basis of conventional medicines and a 
substitute to them ${ }^{21}$. Medicinal plants are ever more employed in dentistry because of the components they enclose. The plants employed in dental pathology have dissimilar therapeutic actions such as antimicrobial, antifungal, antiviral, anti-inflammatory, analgesic and also as endodontic irrigant Table 1. Based on these manifold remedial actions, natural compounds locate their usefulness in a huge amount of dental pathologies.

Table 1 Overview of a various plants employed in dentistry

\begin{tabular}{|c|c|c|c|}
\hline Scientific name & Product & Experiment & Ref \\
\hline \multicolumn{4}{|c|}{ Anti-cariogenic properties of herbal agents } \\
\hline Zingiber officinale & $\begin{array}{l}\text { n-hexane, ethyl acetate, } \\
\text { methanol and aqueous } \\
\text { extracts }\end{array}$ & $\begin{array}{l}\text { Antimicrobial analysis such as biofilm inhibition, time-kill } \\
\text { kinetics, adherence inhibition was conducted }\end{array}$ & 22 \\
\hline Satureja hortensis & $\begin{array}{l}\text { extract and its } \\
\text { essential oil }\end{array}$ & $\begin{array}{l}\text { Antibacterial activity against } S . \text { mutants was evaluated by the } \\
\text { disc diffusion method }\end{array}$ & 23 \\
\hline Salvia officinalis & $\begin{array}{l}\text { Glass-ionomer cement } \\
\text { (GIC) modified with of } S \text {. } \\
\text { officinalis extract }\end{array}$ & $\begin{array}{c}\text { Antibacterial activity against } S \text {. mutants and } L . \text { caseiwas } \\
\text { evaluated by agar disc diffusion method }\end{array}$ & 24 \\
\hline Psidium guajava & $\begin{array}{l}\text { P. guajava leaf extract } \\
\text { used in herbal } \\
\text { toothpaste }\end{array}$ & $\begin{array}{l}\text { Herbal toothpaste was studied for its antimicrobial activity } \\
\text { against, S.aureus, S. mutants, Bacillus subtilis, S. oralis, and } \\
\text { Proteus vulgaris }\end{array}$ & 25 \\
\hline Vaccinium vitis-idaea & Polyphenol-rich fraction & $\begin{array}{l}\text { Evaluation of biofilm formation ability and bioactivity of } S \text {. } \\
\text { mutants, S. sobrinus, and S. sanguinis }\end{array}$ & 26 \\
\hline Tinospora cordifolia & Ethanolic extract & $\begin{array}{l}\text { Seven different concentrations were prepared and tested } \\
\text { against } S \text {. mutans in brain-heart infusion agar medium }\end{array}$ & 27 \\
\hline $\begin{array}{l}\text { Glycyrrhizaglabra/ } \\
\text { Terminalia chebula }\end{array}$ & $\begin{array}{l}\text { G. glabra and T. chebula } \\
\text { extracts }\end{array}$ & $\begin{array}{l}\text { The anti-adherence property of the herbal extract was } \\
\text { evaluated using a glass surface adherence test }\end{array}$ & 28 \\
\hline Trachyspermum ammi & T. ammi oil & $\begin{array}{l}\text { Serial dilution and disc diffusion method was used for } \\
\text { evaluation of T. ammi antibacterial efficacy }\end{array}$ & 29 \\
\hline Mentha piperita & M. piperita leaf extract & $\begin{array}{l}\text { Anti-microbial activity of the M. piperita was tested by the } \\
\text { disc diffusion method }\end{array}$ & 30 \\
\hline Camellia sinensis & $\begin{array}{l}\text { The esterified derivative } \\
\text { of EGCG }\end{array}$ & $\begin{array}{l}\text { The number of colony-forming units was assessed for } \\
\text { evaluation of EGCG efficiency against cariogenic bacteria }\end{array}$ & 31 \\
\hline Psoraleae semen & $\begin{array}{l}\text { P. semen ethanolic } \\
\text { extract }\end{array}$ & $\begin{array}{c}\text { Protein leakage evaluation and scanning electron microscopy } \\
\text { was conducted to determine the efficacy of P. semen against } \\
\text { bacterial cell membrane }\end{array}$ & 32 \\
\hline Punica granatum & P. granatum gel & $\begin{array}{c}\text { Agar well diffusion method was used for evaluation of P. } \\
\text { granatum against cariogenic bacteria such as S. sanguis, S. } \\
\text { mutans, and L. casei }\end{array}$ & 33 \\
\hline Galla chinensis & $\begin{array}{l}\text { G. chinensis crude } \\
\text { aqueous extract }\end{array}$ & $\begin{array}{l}\text { Anticariogenic efficacy of G. chinensis was evaluated by tests } \\
\text { like Keyes' caries diagnosis and scoring technique and the } \\
\text { mineral density analysis on molar animal teeth }\end{array}$ & 34 \\
\hline Rosmarinus officinalis & $\begin{array}{l}\text { Alcoholic extract } \\
\text { dentifrice }\end{array}$ & $\begin{array}{l}\text { Single-disc diffusion technique was used for evaluation of } \\
\text { herbal dentifrice against cariogenic bacteria }\end{array}$ & 35 \\
\hline Aloe vera & Aloe vera leaf extract & $\begin{array}{c}\text { Agar and broth microdilution method was used for } \\
\text { antibacterial evaluation }\end{array}$ & 36 \\
\hline Houttuynia cordata & $\begin{array}{l}\text { H.cordata ethanolic } \\
\text { extract }\end{array}$ & $\begin{array}{c}\text { Antibiofilm activity of } H \text {. cordata extract was evaluated } \\
\text { against oral pathogens }\end{array}$ & 37 \\
\hline $\begin{array}{l}\text { Toddalia asiatica/Cortex } \\
\text { Lycii/ Cimicifuga foetida/ } \\
\text { Toddalia asiatica }\end{array}$ & $\begin{array}{l}\text { Herbal mouthwash } \\
\text { (LongZhang Gargle®) }\end{array}$ & $\begin{array}{c}\text { An Agar diffusion test was conducted to determine } \\
\text { antibacterial activity against } S \text {. mutans }\end{array}$ & 38 \\
\hline Cistus incanus & $\begin{array}{l}\text { C. incanus accelerated } \\
\text { solvent extract }\end{array}$ & $\begin{array}{c}\text { A live/dead assay was conducted for evaluation of } C \text {. incanus } \\
\text { herbal extract }\end{array}$ & 39 \\
\hline $\begin{array}{l}\text { Camellia sinensi/Alium } \\
\text { sativum/Citrus } \\
\text { aurantiifolia }\end{array}$ & Herbal mouthwash & $\begin{array}{l}\text { Agar diffusion test was conducted to determine antibacterial } \\
\text { activity against } S \text {. mutans and } C \text {. albicans }\end{array}$ & 40 \\
\hline
\end{tabular}




\begin{tabular}{|c|c|c|c|}
\hline $\begin{array}{l}\text { Anacardium occidentale/ } \\
\text { Mangifera indica }\end{array}$ & Herbal ethanolic extract & $\begin{array}{l}\text { An Agar diffusion test was conducted to determine } \\
\text { antibacterial activity against } S \text {. mutans and E. faecalis }\end{array}$ & 41 \\
\hline \multicolumn{4}{|c|}{ Herbal medicine and periodontal health maintenance } \\
\hline $\begin{array}{c}\text { Acacia } \\
\text { chundra//Adhatoda } \\
\text { vasica/Mimusops elengi/ } \\
\text { Piper nigrum/Pongamia } \\
\text { pinnata/Quercus } \\
\text { infectoria/Syzygium } \\
\text { aromaticum/ } \\
\text { Terminalia/Zingiber } \\
\text { officinale }\end{array}$ & Ayurvedic herbal extract & $\begin{array}{c}\text { ELISA test was conducted for evaluation of IL-8 production } \\
\text { by immortalized gingival keratinocytes after herbal extract } \\
\text { treatment }\end{array}$ & 42 \\
\hline Hippophae rhamnoides & $\begin{array}{l}\text { H. rhamnoides pulp oil } \\
\text { mouthwash }\end{array}$ & $\begin{array}{c}\text { Biofilm Ring Test was conducted for evaluation of } \mathrm{H} . \\
\text { rhamnoides efficacy against } P \text {. gingivalis, } C \text {. albicans, and } S . \\
\text { gordonii }\end{array}$ & 43 \\
\hline $\begin{array}{l}\text { Cinnamomum } \\
\text { zeylanicum/ Salvadora } \\
\text { persica }\end{array}$ & $\begin{array}{l}\text { Herbal ethanolic } \\
\text { extracts }\end{array}$ & $\begin{array}{l}\text { Agar diffusion test was performed for evaluation of the } \\
\text { antibacterial property of the herbal extract against A. } \\
\text { actinomycetemcomitans and T. forsythia }\end{array}$ & 44 \\
\hline $\begin{array}{l}\text { Acacia nilotica/Murraya } \\
\text { koenigii/Eucalyptus } \\
\text { hybrid/ Psidium guajava }\end{array}$ & Herbal ethanolic extract & $\begin{array}{c}\text { An Agar diffusion test was conducted to determine } \\
\text { antibacterial activity against P. gingivalis and F. nucleatum }\end{array}$ & 45 \\
\hline $\begin{array}{l}\text { Allium sativum/Ziziphora } \\
\text { clinopodioides }\end{array}$ & $\begin{array}{l}\text { Z. clinopodioides and } A \text {. } \\
\text { sativum essential oil }\end{array}$ & $\begin{array}{c}\text { The broth macro dilution method and disk diffusion } \\
\text { technique were conducted to evaluate the activity of essential } \\
\text { oils on S. aureus and P. aeruginosa. }\end{array}$ & 46 \\
\hline Houttuynia cordata & $\begin{array}{l}\text { The decoction of dried } \\
\text { H. cordata leaves }\end{array}$ & $\begin{array}{c}\text { The microbial broth dilution method was used for evaluation } \\
\text { of } H \text {. cordata antibacterial property }\end{array}$ & 47 \\
\hline Polygoni multiflori & $\begin{array}{l}\text { 2,3,5,4- } \\
\text { Tetrahydroxystilbene-2- } \\
\text { O-beta-glucoside (THSG) }\end{array}$ & $\begin{array}{l}\text { Evaluation of modulatory property of THSG on inflammatory } \\
\text { responses caused by P. gingivalis in gingival fibroblasts }\end{array}$ & 48 \\
\hline Morus alba & ethanolic extract & $\begin{array}{c}\text { Antibacterial efficacy of the ethanolic extract was assessed by } \\
\text { estimating minimum inhibitory concentration against } \\
\text { common periodontal pathogens }\end{array}$ & 49 \\
\hline Amellia sinensis & A. sinensis solution & $\begin{array}{l}\text { Expression of interleukin-10, tumor necrosis factor and } \\
\text { RANKL in diabetic rats were evaluated after treatment with } \\
\text { A. sinnensis solution by immunohistochemistry }\end{array}$ & 50 \\
\hline VitisViniferea & $\begin{array}{l}\text { Commercially available } \\
\text { grape seed extract }\end{array}$ & $\begin{array}{c}\text { Brekoex Grape seed OPC } 30 ® \text { The modified agar dilution } \\
\text { millpore method was conducted for evaluation of seed } \\
\text { extract antibacterial property against } S \text {. aureus, E. coli, } C \text {. } \\
\text { albicans, and K. pneumonia }\end{array}$ & 51 \\
\hline \multicolumn{4}{|c|}{ Herbal medications and endodontic treatments } \\
\hline $\begin{array}{l}\text { Myrtus } \\
\text { Communis/Eucalyptus } \\
\text { Galbie }\end{array}$ & $\begin{array}{l}\text { Methanolic extracts in } \\
\text { combination with } \\
\text { calcium hydroxide } \\
\text { powder }\end{array}$ & $\begin{array}{c}\text { Agar diffusion technique, tube dilution test, and microtiter } \\
\text { plate assay were conducted for evaluation of antibacterial } \\
\text { activity against E. faecalis }\end{array}$ & 52 \\
\hline $\begin{array}{l}\text { Angelica } \\
\text { archanglica/Asurum } \\
\text { European }\end{array}$ & $\begin{array}{l}\text { Fufang bing peng } \\
\text { irrigant }\end{array}$ & $\begin{array}{c}\text { PCR, high-throughput sequencing analyses, and antibacterial } \\
\text { test were conducted to evaluate the efficacy of the herbal } \\
\text { irrigant against E. faecalis }\end{array}$ & 53 \\
\hline $\begin{array}{l}\text { Emblica officinalis/ } \\
\text { Terminalia bellirica/ } \\
\text { Terminalia chebula }\end{array}$ & Triphala extract & $\begin{array}{c}\text { Dental canals were examined after rinsing with Triphala } \\
\text { extract for evaluation of the smear layer by field emission } \\
\text { scanning electron microscope }\end{array}$ & 54 \\
\hline Morinda citrifolia & M. citrifolia juice & $\begin{array}{l}\text { Disc and well diffusion tests were conducted for evaluation of } \\
\text { M. citrifoliaa gainst intracanal bacteria such as E. faecalis and } \\
\text { C. albicans }\end{array}$ & 55 \\
\hline $\begin{array}{l}\text { Cymbopogon citratus/ } \\
\text { Mentha piperita/ Ocimum } \\
\text { sanctum }\end{array}$ & $\begin{array}{l}\text { NaOCl herbal solution } \\
\text { (9:1 ratio) }\end{array}$ & $\begin{array}{l}\text { A combination of } 6 \% \mathrm{NaOCl} \text { and herbal extracts was tested } \\
\text { for } \mathrm{pH} \text { and chlorine content }\end{array}$ & 56 \\
\hline $\begin{array}{c}\text { Psidium guajava/ } \\
\text { Anacardium occidentale/ }\end{array}$ & Herbal extracts & $\begin{array}{c}\text { An Agar diffusion test was conducted for evaluation of herbal } \\
\text { extracts against } E \text {. faecalis and } C \text {. albicans }\end{array}$ & 57 \\
\hline
\end{tabular}




\begin{tabular}{|c|c|c|c|}
\hline \multicolumn{4}{|l|}{ Carica papaya/Aloe vera } \\
\hline $\begin{array}{l}\text { Morinda citrifolia/ } \\
\text { Emblica officinalis/ } \\
\text { Terminalia bellirica/ } \\
\text { Terminalia chebula }\end{array}$ & $\begin{array}{c}\text { M. citrifolia } \\
\text { extract/Triphala juice }\end{array}$ & $\begin{array}{c}\text { Colony-forming units of } E \text {. faecalis and } C \text {. albicans were } \\
\text { evaluated after intracanal irrigation with Triphala juice, } M \text {. } \\
\text { citrifolia extract and CHX }\end{array}$ & 58 \\
\hline Curcuma longa & C. longa gel & $\begin{array}{l}\text { Evaluation of anti-bacterial property of } C \text {. longa against } E \text {, } \\
\text { faecalis infection found in dentinal tubules }\end{array}$ & 59 \\
\hline $\begin{array}{l}\text { Cymbopogon citratus/ } \\
\text { Ocimum basilicum/ } \\
\text { Camellia sinensis }\end{array}$ & $\begin{array}{l}\text { C. citarus oil/ } O \text {. } \\
\text { basilicum oil/obicure tea } \\
\text { extract }\end{array}$ & $\begin{array}{l}\text { Broth micro dilution method was used for evaluating the } \\
\text { antimicrobial efficacy of herbal extracts against } \text { E. faecalis } \\
\text { found on gutta-percha cones }\end{array}$ & 60 \\
\hline $\begin{array}{l}\text { Emblica officinalis/ } \\
\text { Psidium guajava }\end{array}$ & Alcoholic extracts & $\begin{array}{l}\text { The Agar disk-diffusion method was used for evaluating the } \\
\text { efficiency of herbal extracts and BioPure MTAD® against } E \text {. } \\
\text { faecalis }\end{array}$ & 61 \\
\hline $\begin{array}{c}\text { Morinda citrifolia,/ } \\
\text { Azadirachta indica/ Aloe } \\
\text { vera }\end{array}$ & Aqueous extracts & $\begin{array}{l}\text { An Agar diffusion test was conducted for evaluating herbal } \\
\text { extract's efficacy against E. faecalis }\end{array}$ & 62 \\
\hline Allium sativum & Water extract & $\begin{array}{c}\text { Fluorescence microscopic analysis and microbial viability } \\
\text { assay were used for evaluation of antibacterial efficacy } \\
\text { against } E \text {. faecalis }\end{array}$ & 63 \\
\hline Ferula gummosa & F. gummosa essential oil & $\begin{array}{l}\text { Broth micro-dilution evaluation and disk diffusion test were } \\
\text { conducted to evaluate the antibacterial efficacy of } F \text {. } \\
\text { gummosa oil }\end{array}$ & 64 \\
\hline \multicolumn{4}{|c|}{ Herbal medicine and anti-fungal properties } \\
\hline Nigella Sativa & Alcoholic extract & $\begin{array}{l}\text { Candida colony count evaluation was conducted after rinsing } \\
\text { C. albicans-contaminated acrylic resin specimens with } N . \\
\text { sativa extract }\end{array}$ & 65 \\
\hline $\begin{array}{l}\text { Equisetum giganteum/ } \\
\quad \text { Punica granatum }\end{array}$ & $\begin{array}{l}\text { Combination of herbal } \\
\text { ethanolic extracts with } \\
\text { denture adhesive }\end{array}$ & $\begin{array}{c}\text { Evaluation of the herbal extracts' efficacy against } C \text {. albicans } \\
\text { by confocal laser scanning microscopy analysis, colony- } \\
\text { forming units count, cell viability analysis, and scanning } \\
\text { electron microscopy }\end{array}$ & 66 \\
\hline Isodon flavidus & Methanolic extract & $\begin{array}{l}\text { Evaluation of anti-fungal property of I. flavidus by biofilm } \\
\text { breakdown assay against } C \text {. albicans and T. rubrum }\end{array}$ & 67 \\
\hline Lippia citriodora & $\begin{array}{l}\text { Aqueous and ethanolic } \\
\text { extract }\end{array}$ & $\begin{array}{c}\text { Evaluation of anti-fungal property of L. citriodora by the disk } \\
\text { and well diffusion tests }\end{array}$ & 68 \\
\hline $\begin{array}{l}\text { Centratherum } \\
\text { anthelminticum/Ocimum } \\
\text { sanctum }\end{array}$ & Seed oils & $\begin{array}{l}\text { Evaluation of anti-fungal property of herbal oils by disc } \\
\text { diffusion and broth micro dilution methods }\end{array}$ & 69 \\
\hline Zataria multiflora & $\begin{array}{l}0.5 \mathrm{mg} / \mathrm{ml} \text { Z. multiflora } \\
\text { extract }\end{array}$ & $\begin{array}{l}\text { Evaluation of anti-fungal property of Z. multiflora herbal } \\
\text { extract against } C \text {. albicans by mean viable microbial count }\end{array}$ & 70 \\
\hline Origanumdubium & $\begin{array}{l}\text { Origanum oil combined } \\
\text { with tissue conditioner }\end{array}$ & $\begin{array}{l}\text { Evaluation of anti-fungal property of } O \text {. dubium herbal extract } \\
\text { against } C \text {. albicans by agar punch well method }\end{array}$ & 71 \\
\hline \multicolumn{4}{|c|}{ Anti-inflammatory and wound healing properties } \\
\hline $\begin{array}{l}\text { P. ginseng/G. glabra/Z. } \\
\text { jujuba/P. ternata/Z. } \\
\text { officinale/ } \\
\text { Scutellaria/Coptis }\end{array}$ & Hangeshashinto & $\begin{array}{l}\text { Evaluation of the effects of Hangeshashinto on scratch } \\
\text { induced wound healing in vitro and in vivo }\end{array}$ & 72 \\
\hline Schisandtrin chinensis & Schisandrin $C$ & $\begin{array}{l}\text { Evaluation of reactive oxidative stress and nitric oxide } \\
\text { production in dental pulp cells by muse cell analysis }\end{array}$ & 72 \\
\hline Camellia sinensis & Herbal extract & $\begin{array}{c}\text { Evaluation of inflammatory cell infiltration in oral epithelium } \\
\text { after treatment with } C \text {. sinensis herbal extract in rats by } \\
\text { histological analysis }\end{array}$ & 74 \\
\hline \multicolumn{4}{|c|}{ Antineoplastic properties in herbal medications } \\
\hline Geranium thunbergii & Geraniin & $\begin{array}{l}\text { Evaluation of anti-neoplastic property of Geraniin against SCC } \\
\text { cells by western blot assay }\end{array}$ & 75 \\
\hline Vernonia cinerea & $\begin{array}{c}8 \alpha- \\
\text { tigloyloxyhirsutinolide- }\end{array}$ & Evaluation of anti-proliferative property of $8 \alpha \mathrm{TGH}$ against & 76 \\
\hline
\end{tabular}




\begin{tabular}{|c|c|c|c|}
\hline & 13-0-acetate & SCC cells by SRB colorimetric method & \\
\hline Syzygium cumini & Herbal extract & $\begin{array}{l}\text { Evaluation of anti-proliferative property of } S \text {. cumini against } \\
\text { SCC cell lines by MTT assay }\end{array}$ & 77 \\
\hline Eclipta prostrata & Herbal extract & $\begin{array}{c}\text { Evaluation of E. prostrata property on metastasis promoting } \\
\text { proteins production in SCC cell lines }\end{array}$ & 78 \\
\hline Rheum palmatum & Herbal extract & $\begin{array}{l}\text { Evaluation of } R . \text { palmatum herbal extract against SCC cell } \\
\text { metastasis by western blot and gelatin zymography }\end{array}$ & 79 \\
\hline $\begin{array}{l}\text { Nigella sativa/Aloe vera/ } \\
\text { Salvadora persica }\end{array}$ & Herbal extracts & $\begin{array}{l}\text { Evaluation of anti-neoplastic property of herbal extracts } \\
\text { against HeLa cell lines }\end{array}$ & 80 \\
\hline Salvia miltiorrhiza & Herbal extract & $\begin{array}{l}\text { property of S. miltorrhiza extracts against oral neoplastic } \\
\text { cells by western blotting analysis }\end{array}$ & 81 \\
\hline $\begin{array}{l}\text { Gynostemma } \\
\text { pentaphyllum }\end{array}$ & Gypenosides & $\begin{array}{l}\text { Evaluation of Gypenosides's effects on cell viability and } \\
\text { apoptosis, and oral neoplastic cell DNA }\end{array}$ & 82 \\
\hline Cudrania tricuspidata & Cudraxanthone $\mathrm{H}$ & $\begin{array}{c}\text { Evaluation of anti-proliferative property of Cudraxanthone } \mathrm{H} \\
\text { against SCC cell lines by western blotting and fluorescent } \\
\text { nuclear staining }\end{array}$ & 83 \\
\hline \multicolumn{4}{|c|}{ Bone regeneration and herbal medicine } \\
\hline $\begin{array}{l}\text { G. glabra/V. vinifera/A. } \\
\text { officinarum/U. dioica/S. } \\
\text { aromaticum/S. vulgaris/ } \\
\quad \text { H. perforatum }\end{array}$ & Mecsinahemostopper & $\begin{array}{c}\text { Evaluation of hard tissue regeneration by using histologic and } \\
\text { radiologic analyses after treatment with the herbal agent and } \\
\text { low-level laser therapy in rats }\end{array}$ & 84 \\
\hline Morinda citrifolia & Aqueous extract & $\begin{array}{l}\text { Evaluation of osteogenic differentiation in human periodontal } \\
\text { ligament cells after treatment with } M \text {. citrifolia }\end{array}$ & 85 \\
\hline Aloe vera & Acemannan & $\begin{array}{l}\text { Evaluation of bone formation after tooth extraction by dual- } \\
\text { energy X-ray absorptiometry and histologic analysis }\end{array}$ & 86 \\
\hline
\end{tabular}

\section{Toxicity}

There are several people which claim herbalmedicines to be devoid of side effects that is amyth. There still are masses which still completelydepend on herbal medicine so much so that havereplaced the daily prescribed dose of allopathicfor diabetes, hypertension, thyroid disease, etc ${ }^{87-90}$ with herbal medicines where the patient have pledged to have the medicines lifelong. There are several sites online which are trying to trade herbal medicines under the tag of being free from side effects. In countries like India which are in the race of becoming a developed country no regulations and laws are made against the trade of Ayurveda medicines which use herbs and their extracts. People are drawn to such traders and start using herbal medicines under the notion of them being free from side effects ${ }^{91},{ }^{92}$. However toxicities due to herbalism can be due to improper intake, self-treatment as they are easily available in the market, under qualified practitioners and intake of sub standard products. Herbs manifest their toxicities in the form of nephrotoxicity, cardio toxicity, hepatotoxicity, neurotoxicity and skin toxicity ${ }^{19-95}$. Various manifestations of most commonly used herbs are indicated in the Table 2 along with their recommended indications ${ }^{96}$.

\section{Table 2 Manifestations of plants}

\begin{tabular}{|l|l|l|l|}
\hline Name & Toxicity & Indication & Ref. \\
\hline Cranberry & Nephrolithiasis & Dietary supplement & 97 \\
\hline Willow Bark & Renal Dysfunction & Anti Rheumatic & 98 \\
\hline Aconite, Monks Hood & Ventricular Arrhythmia & Pain & 99 \\
\hline Black Cohosh & Acute hepatitis & Menopausal symptoms & 100 \\
\hline Kava kava & Acute liver failure & Tranquilizer & 101 \\
\hline Valerian & Liver toxicity & Sedative & 102 \\
\hline
\end{tabular}

\section{CONCLUSION}

Herbal medicine has gained considerable popularity during the past decade. The chief benefits of using natural options are easy accessibility, cost-effectiveness, improved shelf life, low toxicity and lack of microbial confrontation accounted up to now. Herbal agents have been employed in dentistry for plummeting inflammation, as antifungal, antibacterials, antimicrobial plaque agents, antiseptics, antioxidants, antimicrobials, antivirals, and analgesics. They also help in healing and are efficient in scheming microbial plaque in gingivitis and periodontitis and thus improving immunity. Many researchers in the meadow of dentistry and pharmacology have devoted their time and resources to evaluation of natural products, discovering their bioactive 
compounds and finding applications for them in a variety of features of oral health maintenance. In this paper, we tried to create a complete review of recent scientific studies about medicinal plants and their current status in the meadow of dentistry. The gathered data can be employed as a basis for future endeavors to discover novel natural medicaments with lower costs and side effects for oro-dental pathologies.

\section{Future Direction}

Herbal medicine shows assure consequences in almost every aspect of oro-dental treatment plans. Although numerous of the studies with reference to the beneficial properties of herbal medicine in dentistry claim that herbal products can be employed as alternatives for conventional drugs, without bearing common side effects, the majority of them lack proper evidence about their protection and biocompatibility. Most of these researches are conducted at in-vitro and preclinical settings. Therefore, there is an urgent need to increase research efforts and funding aimed at clinical trials on efficacy, safety, cost-effectiveness, and characterization of these natural compounds. Alternative and herbal therapy can be helpful for the people all around the earth, especially in resource limited countries. This can support and justify the requirement for upcoming studies with up to date and reliable protocols and techniques.

\section{Funding}

There was no financial support.

\section{Conflict of interest}

None

\section{References}

1. Palombo EA. Traditional medicinal plant extracts and natural products with activity against oral bacteria: potential application in the prevention and treatment of oral diseases. Evid Based Complement Alternat Med 2011; 2011:680354. https://doi.org/10.1093/ecam/nep067

2. Porwal O, Singh SK, Patel DK, Gupta S, Tripathi R, Katekhaye S. Cultivation, Collection and Processing of Medicinal Plants. Bioactive Phytochemicals: Drug Discovery to Product Development. 2020:14-30. https://doi.org/10.2174/9789811464485120010005

3. Ramanunny AK, Wadhwa S, Gulati M, Gupta S, Porwal O, Jha NK, et al., Development and validation of RP-HPLC method for 1'Acetoxychavicol acetate (ACA) and its application in optimizing the yield of ACA during its isolation from Alpiniagalanga extract as well as its quantification in nanoemulsion. S Afr J Bot 2021. https://doi.org/10.1016/j.sajb.2021.10.012

4. Oncag O, Cogulu D, Uzel A, Sorkun K. Efficacy of propolis as an intracanal medicament against Enterococcus faecalis. Gen Dent 2006; 54:319-322.

5. Sood A, Kumar B, Singh SK, Prashar P, Gautam A, Gulati M, et al., Flavonoids as potential therapeutic agents for the management of diabetic neuropathy. Curr Pharma Des 2020; 26(42):54685487. https://doi.org/10.2174/1381612826666200826164322

6. Singh S, Singh SK, Kumar B, Kaur B, Khursheed R, Gulati M, et al., Effect of co-administration of herbal extracts with copper nanoparticles: a novel two-pronged approach in treating type 2 diabetes. Recent Innov Chem Eng2020; 13(5):366-378. https://doi.org/10.2174/2405520413999200719140819

7. Banerjee M, Khursheed R, Yadav AK, Singh SK, Gulati M, Pandey DK, et al., A systematic review on synthetic drugs and phytopharmaceuticals used to manage diabetes. Curr Diabetes Rev 2020; 16(4):340-356. https://doi.org/10.2174/1573399815666190822165141
8. Porwal O, Nanjan MJ, Chandrasekar MJN, Srinivasan R, Gupta S. Anticancer potential of solanumjasminoides. Int J Pharm Sci Res 2014; 5(9):3768-3774.

9. Chandrasekar MJN, Srinivasan R, Porwal O, Nanjan MJ. In-Vitro antioxidant activity of solanum jasminoides paxt extracts. J Nat Remedies. 2012; 12(2):115-118.

10. Vishwas S, Gulati M, Kapoor B, Gupta S, Singh SK, Awasthi A, et al., Expanding the arsenal against Huntington's disease-Herbal drugs and their nanoformulations. Curr Neuropharmacol 2021; 19(7):957-989. https://doi.org/10.2174/1570159X18666201109090824

11. Malviya R, Raj S, Fuloria S, Subramaniyan V, Sathasivam K, Kumari U, et al., Evaluation of antitumor efficacy of chitosantamarind gum polysaccharide polyelectrolyte complex stabilized nanoparticles of simvastatin. Int J Nanomed 2021; 16:2533-2553. https://doi.org/10.2147/IJN.S300991

12. Kabra P, Loomba K, Kabra SK, Majumdar DSP, Kumar N. Medicinal plants in the treatment of dental caries. Asian J Oral Health Allied Sci 2012; 2(1): 12-16.

13. Calixto JB. Efficacy, safety, quality control, marketing and regulatory guidelines for herbal medicines (phytotherapeutic agents). Braz J Med Biol Res 2000; 33:179-189. https://doi.org/10.1590/S0100-879X2000000200004

14. Petersen PE. The World Oral Health Report 2003: continuous improvement of oral health in the 21st century-the approach of the WHO Global Oral Health Program Community Dentistry and Oral Epidemiology 2003; 31(1):3-24. https://doi.org/10.1046/j..2003.com122.x

15. Hussain FHS, Amin HIM, Patel DK, Porwal O. An overview of the therapeutic potential of Iris persica. Curr Tradit Med 2021; $7(2): 152-160$.

https://doi.org/10.2174/2215083806666200117111320

16. Porwal O, Gupta S, Nanjan MJ, Singh A. Classical taxonomy studies of medicinally important Ipomoea leari. Ancient science of life. 2015; 35(1):34. https://doi.org/10.4103/02577941.165628

17. Petersen P, Kwan S. The 7 (Th) WHO Global Conferences on Health Promotion-towards Integration of Oral Health (Nairobi, Kenya 2009). Community Dent Health 2021; 26:1109.

18. Petersen PE, Bourgeois D, Ogawa H, Estupinan-Day S, Ndiaye C The global burden of oral diseases and risks to oral health bull. World Health Organ 2005; 83:661-669.

19. Jenkinsonand HF, Lamont RJ. Oral microbial communities in sickness and in health. Trends Microbiol 2005; 13(12):589-95. https://doi.org/10.1016/j.tim.2005.09.006

20. Rodrigues F, Lehmann M, do Amaral VS, Reguly ML, de Andrade HHR. Genotoxicity of three mouthwash products, cepacol, periogard, and plax, in the drosophila wing-spot test environ. Mol Mutagen 2007, 48,:644-649. https://doi.org/10.1002/em.20332

21. Taheri JB, Azimi S, Rafieian N, Akhavan Zanjani H. Herbs in dentistry. Int Dent J 2011; 61:287-296. https://doi.org/10.1111/j.1875-595X.2011.00064.x

22. Babaeekhou L, Ghane M. Antimicrobial activity of ginger on cariogenic bacteria: molecular networking and molecular docking analyses. J Biomol Struct Dyn 2020; 1-12. https://doi.org/10.1080/07391102.2020.1745283

23. Hagh LG, Arefian A, Farajzade A, Dibazar S, Samiea N. The antibacterialactivity of "Saturejahortensis" extract and essential oil against oral bacteria. Dent Res J 2019; 16:153-159. https://doi.org/10.4103/1735-3327.255741

24. Shahriari S, Barekatain M, Shahtalebi MA, Farhad SZ, Evaluation of preventive antibacterial properties of Glass-ionomer cement containing purified powder of salvia officinalis: an invitro study. Int J Prev Med 2019; 10:110. https://doi.org/10.4103/ijpvm.IJPVM_81_17 
25. Shaheena S, Chintagunta AD, Dirisala VR, Sampath Kumar NS. Extraction of bioactive compounds from Psidium guajava and their application in dentistry. Amb Express 2019; 9:208. https://doi.org/10.1186/s13568-019-0935-x

26. Kokubu E, Kinoshita E, Ishihara K. Inhibitory effects of Lingon berry extracts on oral streptococcal biofilm formation and bioactivity. Bull Tokyo Dent Coll 2019; 60:1-9. https://doi.org/10.2209/tdcpublication.2018-0007

27. Agarwal S, Ramamurthy PH, Fernandes B, Rath A, Sidhu P. Assessment of antimicrobial activity of different concentrations of Tinospora cordifolia against Streptococcus mutans: an invitro study. Dent Res J 2019; 16:24-28. https://doi.org/10.4103/1735-3327.249556

28. Bhadoria N, Gunwal MK, Suryawanshi, H, Sonarkar SS. Antiadherence and antimicrobial property of herbal extracts (Glycyrrhiza glabra and Terminalia chebula) on Streptococcus mutans: an invitro experimental study. J OralMaxillofc Pathol 2019; 23:73-77.

29. Dadpe MV, Dhore SV, Dahake PT, Kale YJ, Kendre SB, Siddiqui AG. Evaluation of antimicrobial efficacy of Trachyspermum ammi (Ajwain) oil and chlorhexidine against oral bacteria: an in vitro study. J Indian Soc Pedod Prev Dent 2018; 36: 357-363. https://doi.org/10.4103/JISPPD.JISPPD_65_18

30. Raghavan R, Devi MPS, Varghese M, Joseph A, Madhavan SS, Sreedevi PV. Effectiveness of Mentha piperita leaf extracts against oral pathogens: an in vitro study. J Contemp Dent Pract 2018; 19: 1042-1046. https://doi.org/10.5005/jp-journals10024-2378

31. Melok AL, Lee LH, MohamedYussof SA, Chu T. Green tea polyphenol epigallocatechin-3-gallate-stearate inhibits the growth of Streptococcus mutans: a promising new approach in caries prevention. Dent J 2018; 6 (3):38. https://doi.org/10.3390/dj6030038

32. Kim S, Lee S, Lee H, Ha J, Lee J, Choi Y. et al., Evaluation on antimicrobial activity of psoraleae semen extract controlling the growth of gram-positive bacteria. Korean J Food Sci Anim Resour 2017; 37:502-510. https://doi.org/10.5851/kosfa.2017.37.4.502

33. Millo G, Juntavee A, Ratanathongkam A, Nualkaew N, Peerapattana J, Chatchiwiwattana S. Antibacterial inhibitory effects of Punicagranatum gel on cariogenic bacteria: an in vitro study. Int J Clin Pediatr Dent 2017; 10:152-157. https://doi.org/10.5005/jp-journals-10005-1426

34. Zhang TT, Guo .J, Liu XJ, Chu JP, Zhou XD. Galla chinensis compounds remineralize enamel caries lesions in a rat model. Caries Res 2016; 50(2):159-65. https://doi.org/10.1159/000445036

35. Valones MA, Higino, J. S, Souza PR, Crovella S, Caldas AFJ, Carvalho AA. Dentifrice containing extract of Rosmarinus officinalis Linn. An antimicrobial evaluation. Braz Dent J 2016; 27:497-501. https://doi.org/10.1590/0103-6440201600672

36. Jain S, Rathod N, Nagi R, Sur J, Laheji A, Gupta N. et al., Antibacterial effect of aloe vera gel against oral pathogens: aninvitro study. J Clin Diagn Res 2016; 10:Zc41-zc44. https://doi.org/10.7860/JCDR/2016/21450.8890

37. Sekita Y, Murakami K, Yumoto H, Amoh T, Fujiwara N, Ogata S et al., Preventive effects of Houttuynia cordata extract for oral infectious diseases. Bio Med Res Int 2016; 2581876. https://doi.org/10.1155/2016/2581876

38. Yang Y, Liu S, He Y, Chen Z, Li M. Effect of Long Zhang Gargle on biofilm formation an dacidogenicity of Streptococcus mutans invitro. Bio Med Res Int 2016; 5829823. https://doi.org/10.1155/2016/5829823

39. Wittpahl G, Kolling-Speer I, Basche S, Herrmann E, Hannig M, Speer K, Hannig C. The polyphenolic composition of Cistus incanus herbal tea and its antibacterial and anti-adherent activity against Streptococcus mutans. Planta Med 2015; 81:1727-1735. https://doi.org/10.1055/s-0035-1557822
40. Thomas A, Thakur S, Mhambrey S. Comparison of the antimicrobial efficacy of chlorhexidine, sodium fluoride, fluoride with essential oils, alum, green tea, and garlic with limem out hrinseson cariogenic microbes. J Int Soc Prev Community Dent 2015; 5:302-308. https://doi.org/10.4103/2231-0762.161759

41. Anand G, Ravinanthan M, Basaviah R, Shetty AV. Invitro antimicrobial and cytotoxic effects of Anacardium occidentale and Mangifera indica in oral care. J Pharm Bio Allied Sci 2015; 7:69-74. https://doi.org/10.4103/0975-7406.148780

42. Chang AM, Bamashmous S, Darveau RP, Rajapakse S. An Ayurvedic herbal extract inhibits oral epithelial cell IL-8 responses to host and bacterial agonists. BMC Complement Med Ther 2020; 20:62. https://doi.org/10.1186/s12906-020-28508

43. Smida I, Pentelescu C, Pentelescu O, Sweidan A, Oliviero N, Meuric V, et al., Tamanai-benefits of seabuckthorn (Hippophaerhamnoides) pulp oil-based mouth wash on oral health. J Appl Microbiol 2019; 126:1594-1605. https://doi.org/10.1111/jam.14210

44. Saquib SA, AlQahtani NA, Ahmad I, Kader MA, Al Shahrani SS, Asiri EA. Evaluation and comparison of antibacterial efficacy of herbal extracts in combination with antibiotics on periodontal pathobionts: an in vitro microbiological study. Antibiotics (Basel) 2019; 8. https://doi.org/10.3390/antibiotics8030089

45. ChandraShekar B R, Nagarajappa R, Jain R, Singh R, Suma S, Thakur R. Antimicrobial Efficacy of Acacia nilotica, Murrayakoenigii L. Sprengel, Eucalyptus hybrid, Psidium guajava extracts and their combinations on Fusobacteriumnucleatum and Porphyrom on as gingivalis. Indian J Dent Res 2018; 29:641-645. https://doi.org/10.4103/ijdr.IJDR_52_17

46. Pakdel F, Ghasemi S, Babaloo A, Javadzadeh Y, Momeni R, Ghanizadeh M, et al., Antibacterial effects of garlic extracts and Ziziphora essential oil on bacteria associated with periimplantitis. J Clin Diagn Res 2017; 11:Zc16-zc19. https://doi.org/10.7860/JCDR/2017/24786.9620

47. Sekita Y, Murakami K, Yumoto H, Hirao K, Amoh T, Fujiwara N, Hirota K, et al., Antibio film and anti-inflammatory activities of Houttuynia cordata decoction for oral care. Evid Based Complement Alternat Med 2017; 2850947. https://doi.org/10.1155/2017/2850947

48. Chin YT, Hsieh MT, Lin CY, Kuo PJ, Yang YC, Shih YJ, et al., 2, 3, 5 , 4'-Tetrahydroxystilbene-2-0-beta-glucoside isolated from polygoni multiflori ameliorates the development of periodontitis. Mediat Inflamm 2016; 6953459, 2016. https://doi.org/10.1155/2016/6953459

49. Gunjal S, Ankola AV, Bhat K. Invitro antibacterial activity of ethanolic extract of Morusalba leaf against periodontal pathogens. Indian J Dent Res 2015; 26:533-536. https://doi.org/10.4103/0970-9290.172082

50. Gennaro G, Claudino M, Cestari TM, Ceolin D, Germino P, Garlet GP, deAssis GF. Green tea modulates cytokine expression in the periodontiumand attenuates alveolar bone resorptionin type 1 diabetic rats. PloS One 2015; 10:e0134784. https://doi.org/10.1371/journal.pone.0134784

51. Shrestha B, Theerathavaj ML, Thaweboon S, Thaweboon B. In vitro antimicrobial effects of grape seed extract on periimplantitis microflora in craniofacial implants. Asian Pac J Trop Biomed 2012; 2:822-825. https://doi.org/10.1016/S22211691(12)60236-6

52. Raoof M, Khaleghi M, Siasar N, Mohannadalizadeh S, Haghani J, Amanpour S. ,Antimicrobial activity of methanolic extracts of myrtus communis L. And Eucalyptus Galbie and their combination with calcium hydroxide powder against Enterococcus faecalis. J Dent 2019; 20195:-202.

53. Shi Y, Deng Z, Yang Y, Cui L, Chen T, Hu M. et al., Evaluation of sodium hypochlorite irrigant, bingpeng irrigant, and fufang bingpeng irrigant as endodontic irrigants during passive ultrasonic irrigation. Front Cell Infect Microboil 2019; 9:145. https://doi.org/10.3389/fcimb.2019.00145 
54. Susan AC, Bharathraj AR, Praveen M, Kumar NSM, Karunakaran $\mathrm{JV}$. Intra radicular smear removal efficacy of triphala final rinse solution in curved canals: a scanning electron microscope study. J Pharm Bio Allied Sci 2019; 11:S420-s428. https://doi.org/10.4103/JPBS.JPBS_55_19

55. Singh M, Singh S, Salgar A R, Prathibha N, Chandrahari N, Swapna LA. An invitro comparative evaluation of antimicrobial efficacy of Propolis, Morinda cordifolia juice, sodium hypochlorite and chlorhexidine on Enterococcusfaecalis and Candida albicans. J Contemp Dent Pract 2019; 20:40-45. https://doi.org/10.5005/jp-journals-10024-2473

56. Pradhan MS, Gunwal M, Shenoi P, Sonarkar S, Bhattacharya S Badole G. Evaluation of $\mathrm{pH}$ and chlorine content of a novel herbal sodium hypochlorite for rootcanal disinfection: an experimental in vitro study. Contemp Clin Dent 2018; 9:S74s78. https://doi.org/10.4103/ccd.ccd_60_18

57. Noushad MC, Balan B, Basheer S, Usman SB, Muhammed Askar MK. Antimicrobial efficacy of different natural extracts against persistent root canal pathogens: an in vitro study. Contemp Clin Dent 2018; 9:177-181. https://doi.org/10.4103/ccd.ccd_754_17

58. Choudhary E, Indushekar KR, Saraf BG, Sheoran N, Sardana D, Shekhar A. Exploring the role of Morinda citrifolia and triphala juice in root canal irrigation: anexvivostudy.JConservDent 2018; 21:443-449. https://doi.org/10.4103/JCD.JCD_58_18

59. Vasudeva A, Sinha DJ, Tyagi SP, Singh NN, Garg P, Upadhyay D. Disinfection of dentinal tubules with $2 \%$ Chlorhexidine gel, Calcium hydroxide and herbal intracanalmedicaments against Enterococcus faecalis: anin-vitrostudy. Singapore Dent J 2017; 38:39-44. https://doi.org/10.1016/j.sdj.2017.06.001

60. Makade CS, Shenoi PR, Morey E, Paralikar AV. Evaluation of antimicrobial activity and efficacy of herbal oils and extracts in disinfection of gutta-percha cones before obstruction. Restor Dent Endod 2017; 42:264-272.

https://doi.org/10.5395/rde.2017.42.4.264

61. Dubey S. Comparative antimicrobial efficacy of herbal alternatives (Emblica officinalis, Psidium guajava), MTAD, and 2.5\% sodium hypochlorite against Enterococcus faecalis: an in vitro study. J Oral Biol Craniofac Res 2016; 6:45-48. https://doi.org/10.1016/j.jobcr.2015.12.010

62. Babaji P, Jagtap K, Lau H, Bansal N, Thajuraj S, Sondhi P. Comparative evaluation of antimicrobial effect of herbal root canalirrigants (Morinda citrifolia, Azadirachta indica, Aloe vera) with sodium hypochlorite: an in vitro study. J Int Soc Prev CommunityDent 2016; 6:196-199.

https://doi.org/10.4103/2231-0762.183104

63. Birring OJ, Viloria IL, Nunez P. Anti-microbial efficacy of Allium sativum extract against Enterococcusfaecalis biofilm and its penetration into the root dentin: an invitro study. Indian J Dent Res 2015; 26:477-482. https://doi.org/10.4103/09709290.172041

64. Abbaszadegan A, Gholami A, Mirhadi H, Saliminasab M, Kazemi A, Moein MR. Antimicrobial and cytotoxic activity of Ferula gummosa plant essential oil compared to $\mathrm{NaOCl}$ and CHX: a preliminary invitro study. Restor Dent Endod 2015; 40:50-57. https://doi.org/10.5395/rde.2015.40.1.50

65. Ariamanesh H, Tamizi N, Yazdinezhad A, Salah S, Motamed N Amanloo S. The effectiveness of Nigella sativa alcoholic extract on the inhibition of Candida albicans colonization and formation of plaque on acrylic denture plates: an invitro study. J Dent 2019; 20:171-177.

66. Almeida NLM, Saldanha LL, daSilva RA, Pinke KH, daCosta EF, PortoVC, Dokkedal AL, Lara VS. Antimicrobial activity of denture adhesive associated with Equisetum giganteum and Punica granatum-enriched fractions against Candida albicans biofilms on acrylicresin surfaces. Bio fouling 2018; 34:62-73. https://doi.org/10.1080/08927014.2017.1407408

67. Li JX, Li QJ, Guan YF, Song X, Liu YH, Zhang JJ, et al., .Discovery of antifungal constituents from the Miao medicinal plant Isodon flavidus. J. Ethnopharmacol 2016; 191:372378. https://doi.org/10.1016/j.jep.2016.06.046
68. Ghasempour M, Omran SM, Moghadamnia AA, Shafiee F. Effect of aqueous and ethanolic extracts of Lippiacitriodora on candida albicans. Electron Physician 2016; 8:2752-2758. https://doi.org/10.19082/2752

69. Aghazadeh M., Zahedi Bialvaei A, Aghazadeh M, Kabiri F, Saliani N, Yousefi M, Eslami H, SamadiKafil H. Survey of the antibiofilm and antimicrobial effects of zingiber officinale (in vitro study). Jundishapur J Microbiol 2016; 9: e30167. https://doi.org/10.5812/jjm.30167

70. Aghili H, JafariNadoushan AA, Herandi V. Antimicrobial effect of zataria multiflora extract in comparison with chlorhexidine mouth wash on experimentally contaminated orthodontic elastomeric ligatures. J Dent 2016; 12:1-10.

71. Srivatstava A, Ginjupalli K, Perampalli NU, Bhat N, Ballal M. Evaluation of the properties of a tissue conditioner containing origanum oil as an antifungal additive. J Prosthet Dent 2013; 110:313-319. https://doi.org/10.1016/S0022-3913(13)603819

72. Miyano K, Eto M, Hitomi S, Matsumoto T, Hasegawa S, Hirano A et al., The Japanese herbal medicine Hangeshashinto enhances oral keratinocyte migration to facilitate healing of chemotherapy-induced oral ulcerative mucositis. Sci Rep 2020; 10:625. https://doi.org/10.1038/s41598-019-57192-2

73. Kim JS, Yi HK. SchisandrinC enhances mitochondrial biogenesis and autophagy in $\mathrm{C} 2 \mathrm{C} 12$ skeletal muscle cells: potential involvement of anti-oxidative mechanisms. NaunynSchmiedeberg's Arch Pharmacol 2018; 391:197-206. https://doi.org/10.1007/s00210-017-1449-1

74. Zaheer N, Shahbaz M, Athar Y, Arshad AI, Zaheer U, Alam, MK Role of green tea extract (Camellia sinensis) in prevention of nicotine induced vascular changes in buccal mucosa of albino rats. Int Med J 2017; 24:120-125.

75. Yeh CM, Hsieh MJ, Yang JS, Yang SF, Chuang YT, Su SC, et al., Gerani in inhibits oral cancer cell migration by suppressing matrix met alloproteinase-2 activation through the FAK/Src and ERK pathways.EnvironToxicol2019;34:1085-1093. https://doi.org/10.1002/tox.22809

76. Pouyfung $\mathrm{P}$, Choonate $\mathrm{S}$, Wongnoppavich $\mathrm{A}$, Rongnoparut $\mathrm{P}$ Chairatvit K, Anti-proliferative effect of 8 alphatigloyloxyhirsutinolide-13-0-acetate (8alphaTGH) isolated from Vernonia cinerea on oral squamous cell carcinoma through inhibition of STAT3 and STAT2 phosphorylation. Phytomedicine 2019; 52:238-246 https://doi.org/10.1016/j.phymed.2018.09.211

77. Ezhilarasan, D, Apoorva VS, Ashok Vardhan N. Syzygium cumini extract induced reactive oxygen species-mediated apoptosis in humanoral squamous carcinoma cells. J Oral Pathol Med 2019; 48:115-121. https://doi.org/10.1111/jop.12806

78. Liao MY, Chuang CY, Hsieh MJ, Chou YE, Lin CW, Chen WR, et al., Antimetastatic effects of Eclipta prostrata extract on oral cancer cells. Environ Toxicol 2019; 33:923-930. https://doi.org/10.1002/tox.22577

79. Chen YY, Hsieh MJ, Hsieh YS, Chang YC, Chen PN, Yang SF, et al., Antimetastatic effects of Rheum palmatum extract on oral cancer cells. Environ Toxicol 2017; 32:2287-2294. https://doi.org/10.1002/tox.22444

80. Amjed S, Junaid K, Jafar J, Amjad T, Maqsood W, Mukhtar N, et al., Detection of antibacterial activities of Miswak, Kalonji and Aloe vera against oral pathogens \& anti-proliferative activity against cancer cell line. BMC Compl Alternative Med 2017; 17:265. https://doi.org/10.1186/s12906-017-1778-0

81. Yang CY, Hsieh CC, Lin CK, Lin CS, Peng B, Lin GJ, et al., Danshen extract circumvents drug resistance and represses cell growth in human oral cancer cells. BMC Compl Alternative Med 2017; 17:555. https://doi.org/10.1186/s12906-017-2063-y

82. Lu KW, Ma YS, Yu FS, Huang YP, Chu YL, et al., Gypenosides induce cell death and alter gene expression in human oral cancer HSC-3 cells. Exp Ther Med 2017; 14: 2469-2476. https://doi.org/10.3892/etm.2017.4840 
83. Lee HJ, Jue SS, Kang SK, Bae WJ, Kim YC, Kim EC. Cudra xanthone $\mathrm{H}$ induces growth inhibition and apoptosis in oral cancer cells via NF-kappa B and PIN1 pathways. Am J Chin Med 2015; 43:1439-1452. https://doi.org/10.1142/S0192415X15500810

84. Ozyurt A, Elmas C, Seymen CM, Peker VT, Altunkaynak B, Gungor MN. Effects of low-level laser therapy with an herbal extract on alveolar bone healing. J Oral Maxillofac Surg 2018; 76:287. https://doi.org/10.1016/j.joms.2017.10.014

85. Gu H, Boonanantanasarn K, Kang M, Kim I, Woo KM, Ryoo HM, Baek JH. Morinda citrifolia leaf extract enhances osteogenic differentiation through activation of wnt/beta-catenin signaling. J Med Food 2018; 21:57-69. https://doi.org/10.1089/jmf.2017.3933

86. Boonyagul S, Banlunara W, Sangvanich P, Thunyakitpisal P. Effect of acemannan, an extracted polysaccharide from Aloe vera, on BMSCs proliferation, differentiation, extracellular matrix synthesis, mineralization, and bone formation in a tooth extraction model. Odontology 2018; 102:310-317. https://doi.org/10.1007/s10266-012-0101-2

87. Malviya R, Sundram S, Fuloria S, Subramaniyan V, Sathasivam $\mathrm{KV}$, Azad AK, et al., evaluation and characterization of tamarind gum polysaccharide: The Biopolymer. Polymers 2021; 13(18):3023. https://doi.org/10.3390/polym13183023

88. Porwal O, Malviya R, Ameen MSM, Anwar ET, Sharma A. A review on effect of various parameters on the rheological behaviour, thermal properties and viscosity of potato starch. Curr Materials Sci 2021; E-pub Ahead of Print https://doi.org/10.2174/2666145414666210521214130

89. Kaur G, Singh SK, Kumar R, Kumar B, Kumari Y, Gulati M, et al., Development of modified apple polysaccharide capped silver nanoparticles loaded with mesalamine for effective treatment of ulcerative colitis. J Drug Del Sci Tech 2020; 60:1-10. https://doi.org/10.1016/j.jddst.2020.101980

90. Som S, Singh SK, Khatik GL, Kapoor B, Gulati M, Kuppusamy G, et al., Quality by design-based crystallization of curcumin using liquid antisolvent precipitation: micromeritic, biopharmaceutical, and stability aspects. Assay Drug Develop Tech2020; 18(1):11-33. https://doi.org/10.1089/adt.2018.913

91. Fatima N. Toxic effects as a result of herbal medicine intake. Toxicology-New Aspects to This Scientific Conundrum. 2016, pp193-207. https://doi.org/10.5772/64468

92. Malviya R, Jha S, Fuloria NK, Subramaniyan V, Chakravarthi S, Sathasivam K, et al., determination of temperature-dependent coefficients of viscosity and surface tension of tamarind seeds (Tamarindus indica l.) polymer. Polymers 2021; 13(4):610. https://doi.org/10.3390/polym13040610

93. Deogade M, Shamrao P, Desai KSR. Efficacy of small group teaching and its comparison with classroom teaching in the subject of dravyaguna. Int J Ayurvedic Med 2017; 8(3):115-133. https://doi.org/10.47552/ijam.v8i3.993

94. Singh A, Porwal O, Sharma N, Singh A, Kumar S, Sharma PK. Effects of Prebiotics on Git and human health: a review. J Pure Applied Microbiol 2007; 1(1):69-82.

95. Anwar ET, Gupta N, Porwal O, Sharma A, Malviya R, Singh A, et al., Skin diseases and their treatment strategies in sub-saharan african regions. Infect Disord Drug Targets. 2021; E-pub Ahead of Print.

https://doi.org/10.2174/1871526521666210927120334

96. Sen S, Chakraborty R. Revival, modernization and integration of Indian traditional herbal medicine in clinical practice: Importance, challenges and future. J Tradit Complemen Med 2017; 7(2):234-244. https://doi.org/10.1016/j.jtcme.2016.05.006

97. Terris MK, Issa MM, Tacker JR. Dietary supplementation with cranberry concentrate tablets may increase the risk of nephrolithiasis. Urology 2001; 57(1):26-29. https://doi.org/10.1016/S0090-4295(00)00884-0

98. Schmid B, Kötter I, Heide L. Pharmacokinetics of salicin after oral administration of a standardized willow bark extract. Eur J Clin Pharmacol 2001; 57(5):387-391. https://doi.org/10.1007/s002280100325

99. Sheth S, Tan EC, Tan HH, Tay L. Herb-induced cardio toxicity from accidental aconitine overdose. Singapore Medical Journal, 2015; 56(07):e116-e119.

https://doi.org/10.11622/smedj.2015114

100. Chow E CY, Teo M, Ring JA, Chen JW. Liver failure associated with the use of black cohosh for menopausal symptoms. Medical Journal of Australia, 2008; 188(7):420-422. https://doi.org/10.5694/j.1326-5377.2008.tb01691.x

101. Gow PJ, Connelly NJ, Crowley P, Angus PW, Hill RL. Fatal fulminant hepatic failure induced by a natural therapy containing kava. Medical J Australia, 2003; 178(9):442-443. https://doi.org/10.5694/j.1326-5377.2003.tb05286.x

102. Willey LB, Mady SP, Cobaugh DJ, Wax PM. Valerian overdose: a case report. Vet Hum Toxicol 1995; 37(4):364-369. 